\title{
Practices of Corporate Governance in the BANKING SECTOR OF BANGLADESH
}

\author{
Rezwan Mahmood ${ }^{1} \&$ Md. Moshin Islam ${ }^{2}$ \\ ${ }^{1}$ Independent Researcher \& Banking Professional, Eastern Bank Ltd, Khulna, Bangladesh \\ ${ }^{2}$ Banking Professional, Shahjalal Islami Bank Limited, Dhaka, Bangladesh
}

\begin{abstract}
Corporate governance became an area of huge interest after the collapse of few giant firms, like Enron Corporation, MCI Inc. etc. Banking sector portraits the whole economy of a country. Bangladesh Bank, the central bank of Bangladesh, provides guidelines for the banking sector and all commercial banks have to follow those guidelines in order to operate their business in Bangladesh. If financial sector collapses, the whole economy will also collapse. Hallmark Group made a BDT 4000 crore scam. Six commercial banks were involved with BDT 200 crore loan scam of Bismillah Group. Basic Bank scam of BDT 4,500 crore loan approval without proper documentation and scrutiny has brought the issue to the fore again. Such fraudulent activities indicate lack of corporate governance practices in the banks. So, this study was initiated to critically observe the current Corporate Governance status and practices in the banking sector of Bangladesh. The study was descriptive in nature. Convenient sampling method was used to select the sample banks for the study. The study found that top management influence as well as political pressure exists in banking sector which affect the lending decisions. Corrupted bankers and dishonest officials of Bangladesh Bank were found associated with several scams. Proper documentation is mandatory but sometimes banks show flexibility in this regards and provide extra benefits to the clients. Selection of wrong borrower, unhealthy competition among the banks, fund diversion, inefficient auditing and insufficient collateral cause major harm to the banks. Sometimes banks do not follow the rules and guidelines provided by Bangladesh Bank properly which were actually designed to protect themselves and operate business smoothly.
\end{abstract}

\section{KEYWORDS}

Corporate Governance, Scam, Bangladesh Bank, Commercial Banks.

\section{INTRODUCTION}

Recent financial scams and increasing default loan size have brought the banking sector of Bangladesh under criticism. Banking sector portraits the whole economy of a country. Undoubtedly, the industry is increasing day-by-day with new banks and their branches. Deposits and credits of these banks are also increasing which have contributed to the economic development of the country. Unfortunately, the health check fails to conceal the problems suffered by the sector from time to time. The current situation of large financial frauds and high non-performing loans (NPL) of banks call for a close scrutiny of this sector and necessitates taking required measures. Between 2010 and 2012, the largest state-owned commercial bank 'Sonali Bank Ltd' illegally distributed loans of BDT 36.48 billion (US\$460 million). The largest share of BDT 26.86 billion (US\$340 million) went to the now infamous Hallmark Group. Other companies those also participated in the fraudulent activities were $\mathrm{T} \&$ Brothers (BDT 6.10 billion); Paragon Group (BDT 1.47 billion); Nakshi Knit (BDT 660 million); DN Sports (BDT 330 million); Khanjahan Ali (BDT 50 million). These were considered to be the country's largest banking scandals. It dwarfs previous fraud cases, such as BDT 6.2 billion Letter of Credit (LC) fraud in Chittagong in 2007, BDT 5.96 billion fraudulent withdrawals from Oriental Bank in 2006, and BDT 3 billion forgery scandals in 2002. The Hallmark group swindled about BDT 3.92 DOI: $10.5121 /$ ijmvsc.2015.6302 
billion from Janata Bank, BDT 3.06 billion from Prime Bank, BDT 1.64 billion from Jamuna Bank, BDT 1.469 billion from Shahjalal Islami Bank and BDT 0.63 billion from Premier Bank by placing counterfeit export documents, taking government's cash incentive to open business firms abroad and with accommodated bills through LCs. Six commercial banks i.e. Premier Bank, Shajalal Islami Bank, Jamuna Bank, Janata Bank, Premier Bank and South-East Bank were involved with BDT 200 crore loan scam of Bismillah Group. Swindlers are not ready to miss a single opportunity to take loans with counterfeit documents as it is so easy in Bangladesh. Basic Bank scam of BDT 4,500 crore loan approvals without proper documentation and scrutiny has brought the issue to the fore again. Board of directors and the top management of the bank were found guilty as the helped those offenders steal the money. The Basic Bank scam rattled the financial sector so much as it has yet to overcome the pinch of a BDT 3,500 crore scam by HallMark and five other companies between 2010 and 2012. Many irregularities regarding loan disbursement of nearly BDT 4,424.93 crore between December 2009 and November 2012 were found by Bangladesh Bank inspection team in Motijheel, Shantinagar, Dilkusha and Gulshan branches of state-owned Basic Bank. Without proper scrutiny of loan documents, Gulshan branch disbursed BDT 1,594.73 crore loans. Basic Bank disbursed BDT 45 crore loans to AB Trade Link and another BDT 112 crore to three other firms i.e. Ma Tex, EFS Enterprise and SPN Enterprise but all these four organizations were found non-existent by the Bangladesh Bank inspection team. In developed countries like USA and European countries, credit card scam is very common where scammers use spyware and some other mechanisms to obtain card details and use those details to withdraw money with a duplicate card. Instances of credit card fraud can be found in India and other Asian countries as well. But a credit card scam involving over BDT 10 crore detected at United Commercial Bank (UCB) was the first such instance in the banking sector of Bangladesh. Four top and mid-level officials of UCB were found guilty who stole the money from the bank by using 21 credit cards in between 2007 and May 2012. Such fraudulent activities indicate lack of corporate governance and its improper practices among the banks. Bangladesh Bank instructed all commercial banks to have strong and healthy corporate governance so that such fraudulent activities can strictly be monitored. So, the main purpose of this study was to critically observe the current Corporate Governance status and practices in the banking sector of Bangladesh.

\section{LITERATURE REVIEW}

Corporate governance is the set of processes, customs, policies, laws, and institutions affecting the way a corporation is directed, administered or controlled. Corporate governance also includes the relationships among the many stakeholders involved and the goals for which the corporation is governed. The principal stakeholders are the shareholders, board of directors, management committee, executive committee and other stakeholders including labour or employees, customers, creditors (e.g., banks, bond holders), suppliers, regulators, and the community at large. For non-profit organizations or other membership organizations the "shareholders" means the "members". Corporate governance is a multifaceted subject. An important theme of corporate governance is to ensure the accountability of certain individuals in an organization through mechanisms that try to reduce or eliminate the principal-agent problem. A related but separate thread of discussions focuses on the impact of a corporate governance system in economic efficiency, with a strong emphasis on shareholders' welfare. There has been renewed interest in the corporate governance practices of modern corporations since 2001, particularly due to the high-profile collapses of a number of large U.S. firms such as Enron Corporation and MCI Inc. (formerly WorldCom). Sarbanes-Oxley Act was passed by US federal government in 2002 aiming to restore public confidence in corporate governance. According to Gabrielle O'Donovan, "corporate governance is an internal system encompassing policies, processes and people, which serve the needs of shareholders and other stakeholders, by directing and controlling management activities with good business savvy, objectivity, accountability and integrity". Sound corporate governance is dependent on external marketplace commitment and legislation, along with a healthy board culture which safeguards policies and processes. O'Donovan also stated that the 
perceived quality of a company's corporate governance can influence its share price as well as the cost of raising capital. Quality is determined by the financial markets, legislation and other external market forces in addition how policies and procedures are executed and how people are directed. External forces are outside the circle of control by any board. Internal environment offers a company the opportunity to differentiate from competitors through their board culture. Many debates have been cantered on legislative policy of corporate governance, to deter fraudulent activities and transparency policy which misleads executives to treat the symptoms and not the cause. It is a system of structuring, operating and controlling a company with a view to achieve long term strategic goals to satisfy shareholders, creditors, employees, customers and suppliers, and complying with the legal and regulatory requirements, apart from meeting environmental and local community needs. Report of SEBI committee (India) on Corporate Governance defines corporate governance as the acceptance by management of the inalienable rights of shareholders as the true owners of the corporation and of their own role as trustees on behalf of the shareholders. It is about commitment to values, about ethical business conduct and about making a distinction between personal and corporate funds in the management of a company. The definition is drawn from the Gandhian principle of trusteeship and the Directive Principles of the Indian Constitution. Corporate Governance is viewed as ethics and a moral duty.

Deposits are blood of a bank which are customers' money that are financed by the banks as investments. If the investments become faulty then it will be the depositors' money that the banks would lose. Such risks demand priority in protection of depositors that ushers in a broader view of corporate governance that suggests the interest and benefits of the suppliers of funds for a firm should be upheld (Shliefer and Vishny, 1997). Macey and O'Hara (2001) also argue that a broader view of corporate governance should be adopted in the case of banking institutions, arguing that because of the peculiar contractual form of banking, corporate governance mechanisms for banks should encapsulate depositors as well as shareholders. Arun and Turner (2003) supported the need for the broader approach to corporate governance for banking institutions and also argue for government intervention to restrain the behaviour of bank management. In many countries, deposit insurance is used as a mechanism to safeguard the banking system as well as the depositors. However, Macey and O'Hara (2001) argues that in many instances, the presence of deposit insurance mechanism by the governments may encourage many bank insiders to embark upon self-benefiting risky deals taking the advantage of insurance protection. The self-dealing activities by the bank insiders are very dangerous to the performance and survival of the banks as scores of previous bank failures have been caused by risky selfdealing by the bank insiders. The presence of heavy liquid assets and potential lack of depositors' interest to actively control and monitor banks' risky decisions as a result of the insurance guarantees simplifies and aggravates the sharking in the banking firms. Banks in developing countries are faced with high risk of sharking as a result of heavy government ownership, lack of prudential regulation, weak legal protection and presence of special interest groups (Arun and Turner, 2003). The independent regulatory agencies are important in developing countries to act against the frequent collusion among government, businesses and bankers to serve special interest groups (Shleifer and Vishny, 1997; Arun and Turner, 2003). However, there is an argument that active role by regulators may cause problems as well, as regulators may not have a convincing/sufficient motivation to monitor the banks as they do not have much at stake in case of bank failures. Recently, the financial markets of developing economies have experienced rapid changes due to the growth of wider range of financial products. As a result of this, banks have been involved with high risk activities such as trading in financial markets and different offbalance sheet activities more than ever before (Greuning and Bratanovic, 2003), which necessitates an added emphasis on quality of corporate governance of banks in developing economies. 
Asian Round Table on Corporate Governance (ARCG) Task force developed the Policy Brief on Corporate Governance of Banks in Asia (June 2006). The main issues and priorities for reforms in Corporate Governance of banks in Asia that were identified are:

- The responsibility of individual board members - fiduciary duties of bank' board members, need of skills, personal abilities, training programs on integrity and professionalism.

- The roles/functions of the board - guiding, approving and overseeing strategies/policies rather than being immersed in day-to-day operations. Creating clear accountability lines and internal control systems. Sufficient flows of information and managerial support.

- The composition of the board - banks are more encouraged to have independent directors than other firms. Separation between Chairman and CEO.

- The committees of the board - audit committee, the Risk Management Committee, The Governance Committee with combined responsibilities of Nomination, remuneration, succession planning, training, performance evaluation, etc.

- Preventing abusive related party transactions - inspection of the existing firewall. Creation of specialized committee to monitor and approve related part transaction. Publicly disclose such transaction.

- Bank holding companies and groups of companies holding banks - a bank's parent company should not impede the full exercise of the Corporate Governance of the bank within the banking group.

- Disclosure - effort on meeting into international standards on accounting, etc. should be encouraged.

- Bank's autonomy in relation to the state - state as owner should respect the legal corporate structures of State Owned Commercial Banks (SOCB).

- Bank's monitoring of the Corporate Governance structure of its corporate borrowers Extent to which banks should assess/monitor Corporate Governance of their corporate borrowers or seek to improve it.

Corporate governance practices in Bangladesh are quite absent in most companies and organizations. In fact, Bangladesh has lagged behind its neighbours and the global economy in corporate governance. One reason for this absence of Corporate Governance is that most companies are family oriented. Moreover, motivation to disclose information and improve governance practices by companies is felt negatively. There is neither any value judgment nor any consequences for corporate governance practices. The current system in Bangladesh does not provide sufficient legal, institutional and economic motivation for stakeholders to encourage and enforce corporate governance practices; hence failure in most of the constituents of corporate governance is witness in Bangladesh. Poor bankruptcy laws, no push from the international investor community, limited or no disclosure regarding related party transactions, weak regulatory system, general meeting scenario, lack of shareholder active participations are some of the individual constituents of corporate governance (Ahmad and Yusuf, 2005).

Bangladesh bank is very much concerned regarding the banking sector of Bangladesh. The 5 state owned banks have more than $2 / 3$ of total classified loans. These banks have $25 \%$ of the total deposits but still they also have $63 \%$ of classified loans in their possession. Bangladesh bank said, inefficient fund management, loan sanction for the political purpose and social and economic responsible compelled them to fall in this situation. The condition of the banking sector is such that if top three borrowers becomes classified then 24 bank among 41 banks will face the capital shortage. Again, if the top 10 borrower of each bank become classified then capital adequacy will lower to $3.5 \%$ though the condition to have capital minimum 10\%. According to central bank loan classification and provisioning report, state owned commercial banks such as Sonali, Janata, Agrahi, Specialized Krishi Bank and Rajshahi Krishi Unnayan Bank have the higher classified 
loans. The situation is worst for the rest for banks except Krishi Bank reported till June-2013. The report has also disclosed that in 2012 the bank made BDT 0.60 profits against every BDT 100 assets. In 2011 it was BDT 1.30. In 2011 the capital adequacy ratio was $11.30 \%$ against risky asset but lowered in 2012 to $10.46 \%$. The report from Bangladesh Bank disclosed that the banking sector has BDT 42725 crore of classified loan till December-2012. Among them three state owned banks and two specialized banks have BDT 26800 crore which consist $62.70 \%$ of total classified loan. It increases in 2013 till June to BDT 52309 crore. That means $63 \%$ of classified loan is possessed by the five banks $67 \%$ of this classified loan is bad loan which means less chance to be recovered. The other 42 banks consists $37.3 \%$ of classified loan. From the last 5 years the banking sector has been deteriorating but the last 2 years was critical time for the banking sector. The state is the owner of these banks and this is the benefit for them. The government is trying to secure the banks by providing capital from tax from the general people. These banks have $25 \%$ of total deposits. State owned basic bank disbursed more than 3500 crore taka fraud loan from malpractice. Without this, the bank associated with the fraud of Hallmark, Bismillah and other big scandal which make them more critical condition. But risk management and corporate governance provided by Bangladesh bank can help them to improve their condition.

\section{Methodology 3.1. Research Type}

The study was both exploratory and descriptive in nature. To serve the objective to the study that is to critically observe the current Corporate Governance status and practices in the banking sector of Bangladesh, we had gone for a descriptive discussion.

\subsection{Sources of Data}

The study was primarily based on information extracted from secondary sources like annual reports, database of Dhaka Stock Exchange (DSE), Bangladesh Bank statistics, different websites, books, journals, newspapers etc. The primary data were collected from a questionnaire survey conducted on top and mid-level management of the affected banks. In-depth interview with a structured questionnaire was used to get their opinion.

\subsection{Population and Sampling}

All the banks operating in Bangladesh was our population for the study. We selected six banks as samples for questionnaire survey. Convenient sampling method which is a non-probability sampling technique was used to select the sample banks for the study. To collect primary data through questionnaire survey from the top and mid-level management, we used judgement sampling method.

\subsection{Data Processing and Interpretation}

Collected data were processed with the help of MS Excel and presented through graphs and descriptive discussions. No statistical tools were used for measuring the data, as the study was descriptive in nature.

\section{ANALYSIS AND DisCUSSION 4.1 Corporate Governance Disclosure and Impact on Classified Loans}

The six banks i.e. Sonali Bank Ltd, Rupali Bank Ltd, Janata Bank Ltd, Basic Bank Ltd, Shahjalal Islami Bank Ltd and The City Bank Ltd disclosed their Corporate Governance compliance 
provided by Bangladesh bank that all the banks must follow. All the credit policies of each bank must be approved by the board of directors. Top management and chief finance officers formulate the credit policies and the policies are approved at board meeting. Sometimes banks failed to communicate their credit policies down the line. In order to make the policies efficient and effective, all the associated officials must know the policies very well. The Sonali bank and Rupali bank lagged behind to communicate their credit policy with down the line properly. But other four banks found sincerely maintain their policy. The credit policy of each bank must reflect the roles and responsibilities of all related officials such as who make proposal, who analysis the loan applications, who disburse loans, who supervise and monitor clients and who recover the loans. From the questionnaire survey it was found that all the six banks' credit policy show specific roles and responsibilities of the associated people but in the informal discussion it was observed that the assigned people do not do their duty properly. As a result, the banks classified loans are increasing day-by-day. The conventional banks follow the Credit Risk Grading and the Islamic Shariah based banks follow Investment Risk Grading. Relationship managers search for the loan clients and that is why they may be biased about their clients. To remove such problem relationship managers should be separated from investment department. In case of lending, age of the borrower should be considered as well. If the person is more than 60 years the banks try to avoid that person from lending. Collateral is very important for the banks for recovery purpose in case of default loans. All the banks ask for collateral but Sonali bank and basic bank failed to investigate mortgaged property properly. The banks have separate teams for reviewing the amount and type of proposed loan, purpose of the loan, the loan structure (i.e. tenor, covenants, repayment schedule, and interest rate), security arrangement etc. The City Bank officials informed that there is no political and management influence on credit department. But other five banks have some pressure on such issues. Among those five, Sonali and Basic bank has acute pressure. Officials from all banks informed that the efficiency of audit team is important in case of detecting fraud and scam. The audit committee must disclose the detected scams to the board of directors to take necessary steps. Sometimes the audit committee has nothing to do because of political and management pressure. From the discussion it was found that conflict of interest exists between the board of director and audit committee. An invisible clash between them were found in some cases i.e. the audit committee tries to detect shortfalls but some members of the board want to ignore those shortfalls.

Half yearly operating profit of the most banks fall short in 2013 due to an increase in default loans, sluggish import and political unrest. Of the 30 banks 20 marked a decline in operating profit, while 10 witnessed a slight rise. Data of the rest was not available at the time of this study. A Bangladesh bank official said that political unrest along with countrywide blockade and violence negatively affected banking business in the first half of the year 2013. The private sector credit growth was $12.7 \%$ in April 213, down from 16.6\% in December 2012, according to Bangladesh Bank data. According to Bangladesh Bank statistics, classified loans were $11.9 \%$ compared to the total outstanding in March 2013, which was $10.03 \%$ last year. Another reason behind lower profit was the fall of interest rate on credit as the liquidity in the banks gone up. On the other hand, the banks interest rate on deposit could not be lowered much which also brought down their profit.

From the figure below, it can be found that the classified loan amount of Sonali Bank Ltd. in 2010 was BDT $68,314.83$ million which was $23.88 \%$ of total investment. In the following year the amount went down but still it was higher at $17.80 \%$ comparing to other banks. But in the year 2012, the amount of classified loan was increased at an alarming rate, $33.31 \%$ of its total investment. Every 100 taka of its investment, there was 33.31 taka of classified loan! That means deposit collected from the general people was in under high risk. 
International Journal of Managing Value and Supply Chains (IJMVSC) Vol. 6, No. 3, September 2015

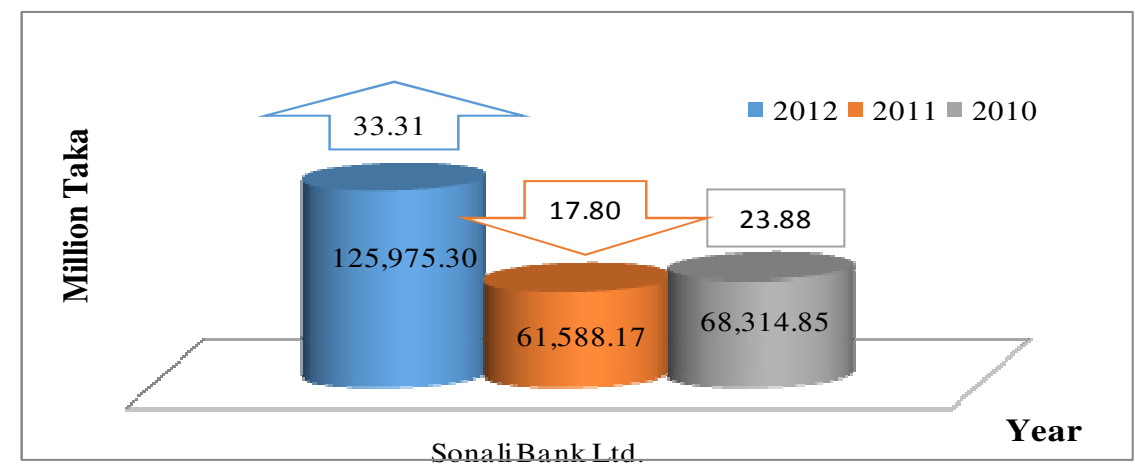

Figure 1: Classified loans and advances of Sonali Bank Ltd in year 2010, 2011 \& 2012

Janata Bank succeeded to keep consistency in its classified loan ratio for the year 2010 and 2011 but the rate went up like a bullet and became $17.16 \%$ in 2012 which also pushed the people's deposit under risk.

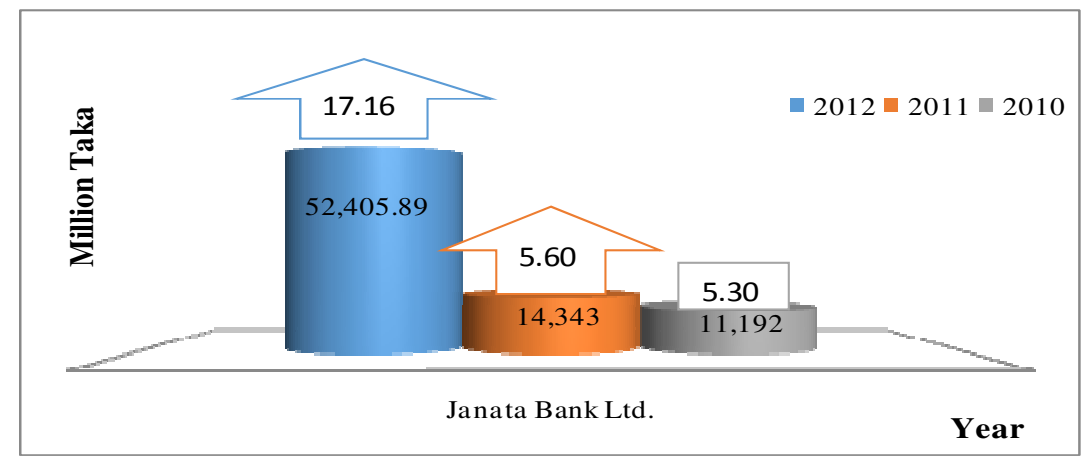

Figure 2: Classified loans and advances of Janata Bank Ltd in year 2010, 2011 \& 2012

In 2010, Rupali Bank Ltd lost its control over the investment and recovery of the loan. For that reason the amount of classified loans became much higher, $11.96 \%$ of its total investment. But in 2011, the percentage of classified loans drastically went down at $5.94 \%$ but in 2012 it again raised drastically.

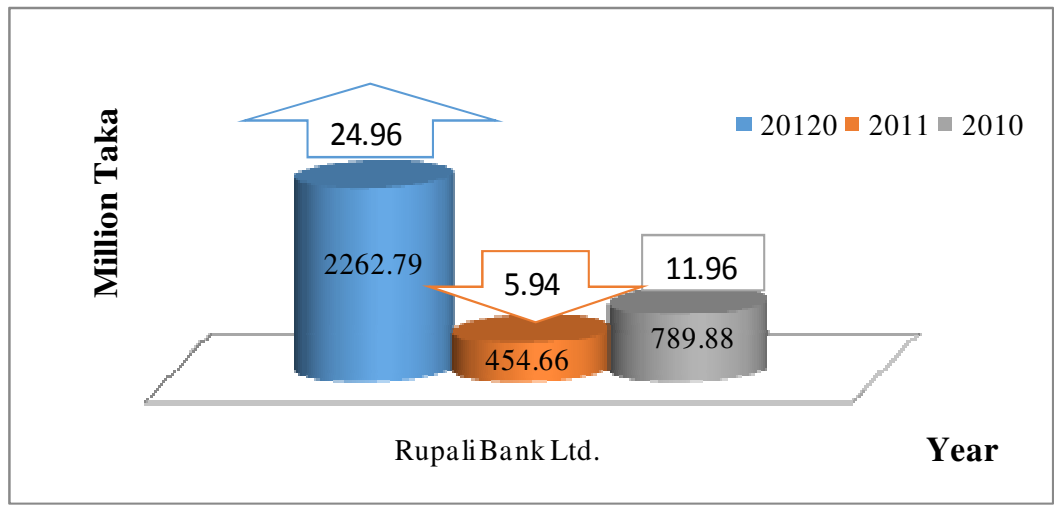

Figure 3: Classified loans and advances of Rupali Bank Ltd in year 2010, 2011 \& 2012 
Now a days, one of the most controversial banks is the Basic Bank Ltd, but this bank was able to control its classified loans amount in the year 2010 and 2011 but in 2012 the bank lost its control over the investment system and as a result the classified loans went up at $8.22 \%$ of its total investment.

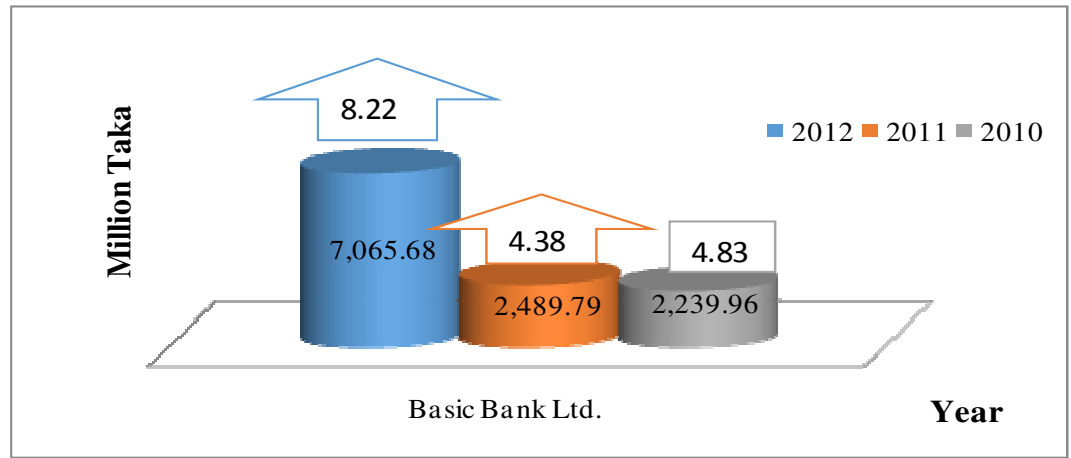

Figure 4: Classified loans and advances of Basis Bank Ltd in year 2010, 2011 \& 2012

Shahjalal Islami Bank Ltd is one of the Islamic Shariah based banks operating in Bangladesh. With the blessings of Islamic Shariah the bank succeeded to limit its classified loan not more than $3.00 \%$ in the previous years.

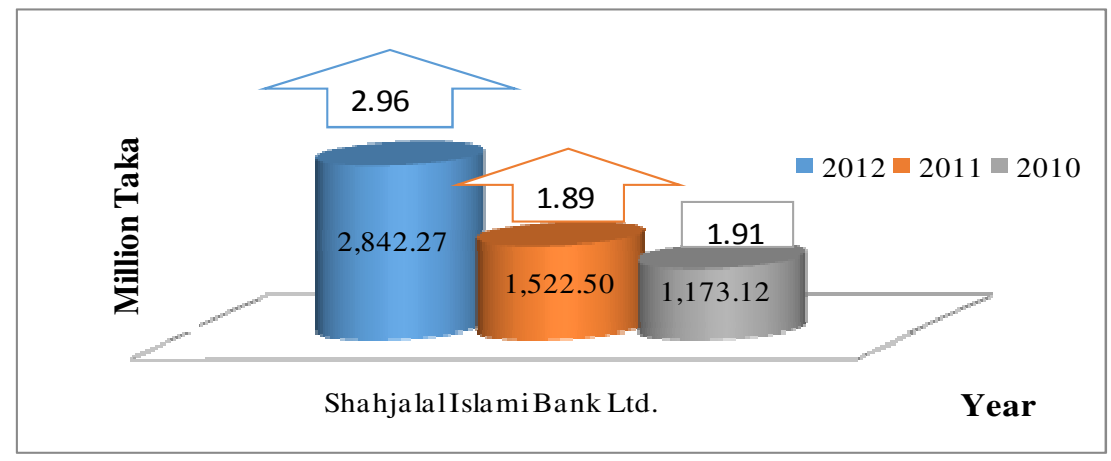

Figure 5: Classified loans and advances of Shahjalal Islami Bank Ltd in year 2010, 2011 \& 2012

The City Bank Ltd, one of the successful banks in Bangladesh, also faced the problem of rising classified loans throughout the country. In 2010 and 2011 percentages of classified loan were only $3.4 \%$ and $4.4 \%$ respectively but in 2012 , it went up to $7.5 \%$.

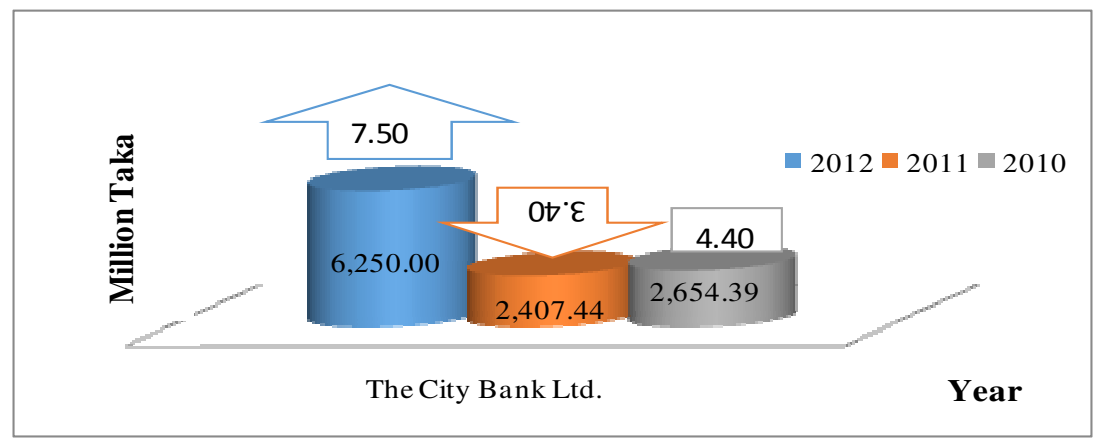

Figure 6: Classified loans and advances of The City Bank Ltd in year 2010, 2011 \& 2012 


\subsection{Discussions}

Borrower Selection Criteria: Some banks are unable to select the right individuals or organizations for lending. If the selection of borrower becomes faulty then the whole lending process will fail. The persons or organizations should be selected as the borrowers who are financially as well as mentally fit for the borrowing. If the banks select the fraud people whose intentions is not to repay the loan then the bank will face higher classified loans thus their banking operations be collapsed. So in case of selection of right borrower, the bank should be knowledgeable or aware of the information of the borrower that is proper KYC (Know Your Customer).

Political Influence: Though the officials informed that there is no political influence in the lending decision making process, there is a suspect of having acute political pressure in this issue. Politically biased decisions lead the loans towards being default and the banking sector towards a vulnerable position. The fraud borrowers are very cunning and they make webs for the people who are associated in lending as well as auditing and reporting process. Politically exposed persons make pressure on the banking sector for themselves as well as for their small fry. For example, in Basic Bank evidence were found that the investment department sent proposal to Head Office as negative but the higher authority made that positive and approved the loan in favour of the client. Investment department and branch manager assumed that the client could be detrimental for the bank and made the proposal negative. But due to having link with high officials and belongingness to a political party, the client became successful to turn the table on him. So, political influence or pressure has an important impact on the banking sector of the Bangladesh.

Management Influence: Like political influence, banks' management has influence on the lending process. The management influence in the credit decision making process and the consequences is higher classified and default loans. The higher management such as Chairman, board of directors, Managing Director, and other high officials have an important command on the lending process. They sometimes show nepotism to their near and dear ones. Sometimes they order and instruct the branch managers to prepare lucrative proposal on behalf of their chosen clients though their loan availing ability is not much lucrative for the bank. Sometimes the management approve loans at a special rate; even with shortage of documents; and not having enough collateral as security.

Involvement of Bangladesh Bank Officials: In an informal discussion with some high officials of different commercial banks as well as with some Bangladesh Bank officials, it has been revealed that some dishonest officials of Bangladesh Bank are also associated in the forgery. Corrupted and dishonest officials take bribe and help to conceal sensitive information of client by not properly analysis the data given by different commercial banks. Sometimes they intentionally overlook fault done by commercial banks during auditing.

Unaware of Bangladesh Bank Circulars: Bangladesh Bank provides circular to the commercial banks time to time for their smooth operation and own safety and security. All commercial banks must have to follow those circulars. It was found that sometimes officials are unaware of those circulars. This may lead the bank towards operational as well as reputational risks.

Incomplete Sanction Advice: Sometimes the credit department sends proposal with incomplete information of the borrower to the Head Office and based on that $\mathrm{HO}$ also issue incomplete sanction advice in favour of the client.

Obligation of Margin in FEX: In foreign exchange, there is an obligation of having minimum $10 \%$ margin of the total Letter of Credit (LC) amount. If the client is unknown to the bank then 
cash margin should be $100 \%$. But the client makes arrangement with the branch officials and keeps the margin to 5\% or sometimes they do not keep the cash margin at all. This is a complete violation of corporate governance of the bank. In case of LC, banks deal with papers not goods. When the documents of LC come to the bank, it must pay the LC amount to the exporter on account of the client/importer. If the client does not repay the amount which was paid to the exporter, the bank then sells the mortgaged property. If the collateral is not enough to secure the loan, the bank cannot be able to recover the full amount which was invested.

Providing Extra Benefits to the Client: Another bad practice was found in the branches is providing extra benefit to the clients. Here the meaning of extra benefit can be defined in different ways. For example, a client's collateral may not enough to get certain amount of loan but getting more than that. In case of foreign exchange, a minimum cash margin is a must but the clients are given extra facility that they do not need to deposit cash prior to the FX transactions. Due to having good relationship with bank officials, sometimes clients ask for deferral of submitting required documents for conducting a specific transaction which is also availing extra benefit. The problem arises when some crucial documents may miss which were mandatory for that transaction. When the fraud was committed, the banks remain unable to show proper documents. A Bangladesh Bank official informed that the classified loan of a certain branch of Prime Bank Ltd was only $2 \%$ to $3 \%$ last year, but for providing extra benefit to the client the classified loan reached to $82 \%$ to $83 \%$ when that client collapsed.

Wrong Information Provided by Head Office: Bangladesh Bank is the central bank and guardian of all commercial banks in Bangladesh. So the commercial banks have to submit different information to Bangladesh Bank through different statements. Based on those information provided by different banks, the central bank takes different decisions and makes policy. Branch offices of each bank provide statements to their respective Head Office. Those statements are finally submitted to Bangladesh Bank. Sometimes branches or even Head Offices temper the actual information. A Bangladesh Bank official informed that when he was doing audit in a branch of Prime Bank, he found a client's loan was classified by the branch office but not by the HO. Such practice is unethical and violation of the rules and regulations of the corporate governance of the bank.

Insufficient Personal Guarantee: Personal guarantee is a popular term in the banking sector. For taking loan from banks guarantee is a must whether it is personal guarantee or collateral. If the loan amount is lower, then the personal guarantee can be taken as the mode of security. But if the amount is higher, then personal guarantee is insufficient and further collateral required. In case of recovery of default loans, personal guarantee is becoming risky.

Lack of Proper Information about Importer and Exporter: Hallmark and Bismillah Group financial scam took place because the bank had not enough and proper information about the importer and exporter. In case of Hallmark, the arrangement of LC was arranged among the different wings of the Hallmark itself. They did not transfer or produce the goods but they submitted the papers to the bank for the payment and the bank made payment of the LC without verification. The Bismillah Group opened its wing in abroad and made the same type of fraud with the bank. So it is necessary for the banks to have complete and proper information regarding the importer as well as the exporter before doing any type of dealings with them.

Investment in Risky Project: The branches have business target to fill up every year and now-adays the competition has increased so much. To survive in the competitive market, banks try to find out different projects where they can invest and get a healthy return. Where there is good return there is also high risk. Investing in high risk projects could make the banks profitable as well as looser sometimes. Another bad practice of competition is hunting of clients at any cost. This practice makes the banks to find clients desperately. For example, a person is capable of getting loan from a bank of amount of taka 50.00 lac as his collateral valuation can support that 
amount maximum but another bank could snatched away that client by offering him more amount. This is very risky and bad practice by the banks. If that client collapses or makes any fraud with the bank, then the bank will be unable to recover its money by selling that collateral.

Monitoring and Supervising Borrower: A bank's main earnings come from loans and advances. So the selection of clients should be done more cautiously by the bank. If the clients' businesses are profitable then they can repay the loan amount to the bank and the bank can also make profit. So it is the responsibility of the bank not only to disburse loan to the clients but also to monitor and supervise how they use the amount and doing their business. This will also prevent fund diversion.

Fund Diversion: Fund diversion is one of the major problems in Bangladeshi banking sector which becomes more crucial now-a-days. The main differences between Islamic and conventional banking system is the mode of disbursement of money. Conventional banks disburse the money directly to the clients account and the clients can do anything with the money they want. They took loan from bank for doing business but if they spend money in any unproductive sector such as invest in share market, buy cars, purchase land, and spend without any goal then the fund becomes diverted. Fund diversion makes the clients unable to make enough return to repay the loan thus the loan fall ultimately. So, strong monitoring and supervision is a must to prevent fund diversion. On the other hand, Islamic banks buy goods for the clients rather disburse money to the clients directly. So, a little chance of fund diversion exists here. But monitoring and supervising is also needed there.

Corrupted Bank Officials: Corrupted bankers are quiet responsible for the financial fraud or scams. They make linkage with the clients and associated with these fraudulent activities. As they know the banking rules and regulations very well and they find the way to do fraud by showing their thumbs to the bank.

Fake Mortgage: Mortgaged property which is used to secure the loan in case of default should be evaluated properly. Sometimes the clients make arrangements of the fake property by making linkage with land officials, legal advisor of the banks and sometimes with the bank officials. Audit team is also responsible because they sometimes overlook such activities intentionally or unintentionally. Hallmark made this type of fraud with Sonali Bank. They mortgaged land as collateral but the land does not exist or the owner is not the Hallmark Group.

Lack of Proper Documentation: Proper documentation is a pre-requisite of every transaction with the clients. If there is any shortage in documentation then the problem might raise during the time of recovery. If the bank becomes unable to show proper documents then it will not get any legal protection while recovering default loans. One instance can be shown that Basic Bank provided loan against fixed deposit which is $100 \%$ secured but in the meantime the client withdrawn the fixed deposit from the bank without settling the loan.

Insufficient Audit: Proper auditing is the main tool that can eradicate all the fraud and scams from the banks. But the audit process cannot be made properly for various reasons. People who are auditing may remain under management pressure or they may be corrupted as well. In some banks, only one audit takes place in a year whereas minimum two audits are mandatory as per rules. 


\section{CONCLUSIONS}

Banking sector portraits the whole economy of a country due to its linkage with all other sectors. It plays a vital role in developing countries like Bangladesh which is now transforming from agriculture based economy to industry based economy. Being the largest unit of financial sector, banks must operate at its best with utmost efficiency to contribute in the economic development of the country. Any shortfall or even a slight instability in this sector would wreck long term havoc on the country's development. Presence of sound corporate governance and its proper practices is the key requirement for efficient and stable banking system. Country like Bangladesh where prudential regulations and supervision is inadequate to provide a safety net for the depositors and stakeholders of the banks, special attention on corporate governance is required on a priority basis. Except few foreign and private commercial banks, most other banks lack quality credit analysis and asset management practices. Insufficient execution of creditor's rights has raised the numbers of classified as well as non-performing loans. Various initiatives have been taken by Bangladesh Bank to improve the asset quality conditions at banks. Still banks have considerable scope to include stringent financial requirements as well as corporate governance factors. Inadequate enforcement of bankruptcy law has made it nearly impossible for a company to close or declare bankrupt which need to be revised for winding up or bankruptcy process specifically for overdue indebtedness reasons. Banking practices and legal ineptitudes regarding financial issues have put the health of the banking sector in a serious qualm. Each factors identified in this study should be examined carefully in order to improving corporate governance practices among the banks for strengthening the banking sector.

\section{REFERENCES}

[1] Arun, T. G. and Turner, J. (2003). Corporate Governance of Banks in Developing Economies: Concepts and Issues. Corporate Governance: An International Review. Vol. 12, No. 3. pp. 371 377.

[2] Ahmad, M. U. and Yusuf, M. A. (2005). Corporate Governance: Bangladesh Perspective. The Cost and Management. Vol. 33 No. 6. pp. 18-26.

[3] Banking Reform Commission (1999): The Report of the Banking Reform Commission. Formed by the Government of Bangladesh.

[4] Bangladesh Enterprise Institute (BEI) (2003): A Comparative Analysis of Corporate Governance in South Asia: Charting a Roadmap for Bangladesh BEI, Dhaka, Bangladesh.

[5] Department of Statistics (2013), Monthly Economic Trends, Bangladesh Bank, December, 2013.

[6] Daily Prothom Alo, "5 State Owner has Highest Classified Loan", Published on Monday, September 16, 2013.

[7] Financial Express, “ACC Quizzes SJIBL Officials over Bismillah Group Loan Scam”, Thursday, April 182013.

[8] Financial Express, "Hallmark-Sonali Bank Loan Scam", Published on Monday, January 14, 2013.

[9] Financial Express, "Sonali Bank vs Hall Mark Group: An Analysis", Published on Sunday, January 6, 2013.

[10] Financial Sector Reform in Bangladesh: An Evaluation. Bank Porikroma. Vol. XXIV, No. 3 \& 4.

[11] Greuning, H. and S. Bratanovic (2003). Analyzing and Managing Banking Risk: A Framework for Assessing Corporate Governance and Financial Risk. World Bank, Washington DC.

[12] Macey, J. and O' Hara, M. (2001). The Corporate Governance of Banks, Federal Reserve Bank of New York, Economic Policy Review.

[13] Shleifer A. and Vishny, R. (1997). A Survey of Corporate Governance. Journal of Finance. Vol. 52, pp. 737-783.

[14] Statistical Yearbook of Bangladesh (2012), Bangladesh Bureau of Statistics, Dhaka, Bangladesh.

[15] The New Nation, "The Role of Banks towards Development of Bangladesh", Published on November 30, 2012.

[16] The Daily Star, "Hall Mark", Published on Tuesday, September 03, 2013.

[17] The Daily Star, "Scam Hits Basic Bank", Published on Friday, June 28, 2013. 


\section{Authors' Profile}

Rezwan Mahmood is an Independent Researcher and a Banking Professional of Eastern Bank Limited, Bangladesh. He received BBA and MBA degree from Khulna University, Bangladesh and PGD in Human Resources Management from Bangladesh Institute of Management under the Ministry of Industries, Bangladesh. He has several publications in international journals. His areas of interest are Marketing, Management and Human Resources Management especially in the service industry.

Md. Moshin Islam completed his Bachelor of Business Administration (BBA) degree and Master of Business Administration (MBA) degree with major in Marketing from Khulna University, Bangladesh. He is a Banking Professional of Shahjalal Islami Bank Limited, Dhaka, Bangladesh. His area of interest is Banking and Management and he has conducted several studies in the field of Bank Management.
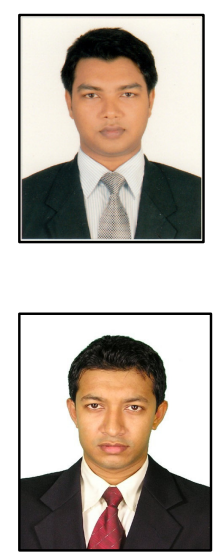